\title{
Role of asphalt paver productivity in direction development of road mechanical engineering
}

\author{
Marina Karpushko ${ }^{1, *}$, and Igor Bartolomei ${ }^{1}$ \\ ${ }^{1}$ Perm National Research Polytechnic University, 614000, Komsomolsky prospekt, 29, Perm, Russia
}

\begin{abstract}
Road construction machinery is one of the largest and stable sectors of national economy. With the help of road-building machinery, construction, maintenance and repair of highways are carried out. Modern system of road and building machines is a complex of high-performance machines and mechanisms, of large and small capacity and productivity. Expansion of paved roads network of both federal and local values, use of resource-saving technologies, increasing of pace and quality of work, ensuring of reliability and durability of highways have a major impact on the development of road construction machinery. The level of foreign road and construction machinery puts forward complex requirements for compliance with world safety and environmental standards, increasing equipment mobility, expanding areas of effective use and, finally, increasing its capacity and productivity. Article contains approach to the calculation of the operational productivity of asphalt pavers that takes into account technical characteristics and conditions of works production and contributes to the reliability of decisions on organization and management of road maintenance works on urban roads.
\end{abstract}

Roads are of strategic importance for any country, and for Russian Federation especially because of the vast territory which it occupies. Their quality, pace of construction, possibility of using fundamentally new technologies, structures and materials, as well as the cost, are largely determined by the availability of modern highway engineering machinery. In this regard, Federal Road Agency Rosavtodor, guided by the Transport Strategy of Russian Federation, develops interdepartmental programs for the development of road machinery.

The main focus is on import substitution, by creating conditions for the production of machinery and equipment on the territory of Russian Federation, rising of technical level and reliability of existing machines, creating fundamentally new models of road construction machinery and equipment. As a result, in recent decades, plants have mastered the production of new models of highway engineering machinery.

Technology of highways construction provides the use of high-performance mechanized links of road machinery. For upper layers of asphalt concrete pavements arrangement, a set consisting of an asphalt paver and a link of road rollers is used. In many aspects the quality and service life of the pavement depends from this set of machines.

Determining factors in the intensity and quality of repair works of hot mix asphalt concrete pavements are: production of the mixture at the asphalt concrete plant, delivery of the mixture to an object by motor transport, preparation of the required existing coating operations, laying and compaction processes of mixture (Figure 1).

\begin{tabular}{|c|c|c|}
\hline \multicolumn{3}{|c|}{ TECHNOLOGICAL PROCESS } \\
\hline $\begin{array}{c}\text { PREPARATORY AND } \\
\text { PRODUCTION OPERATIONS }\end{array}$ & $\begin{array}{c}\text { TRANSPORT } \\
\text { OPERATIONS }\end{array}$ & $\begin{array}{c}\text { OPERATION OF } \\
\text { FORMATION OF } \\
\text { MIXTURE COATING }\end{array}$ \\
\hline I & I & I \\
\hline $\begin{array}{c}\text { TECHNOLOGICAL } \\
\text { PREPARATION OF } \\
\text { PRODUCTION }\end{array}$ & LOADING & $\begin{array}{c}\text { PREPARATION OF THE } \\
\text { SURFACE }\end{array}$ \\
\hline I & I & I \\
\hline MIXING & SHIPPING & LAYING \\
\hline I & I & I \\
\hline $\begin{array}{c}\text { SHIPPING AND STORAGE OF } \\
\text { MIXTURE IN STORAGE BIN }\end{array}$ & UNLOADING, & SEALING \\
\hline
\end{tabular}

Fig. 1. Schematic of the process and operations performed during the repair of asphalt concrete pavement.

The assessment of the selected operations performed on the basis of simulation modeling and collection of statistical data of road-building enterprises work showed that under conditions of sufficient motor transport the intensity of work is mainly determined by the work of the laying link (coefficient of influence 0,565):

$$
I=0,271 \cdot P_{\mathrm{\pi}}^{0,385} W_{\mathrm{T}}^{0,051} P_{\mathrm{y}}^{0,565}
$$

where I - intensity of works; $P_{\text {п }}$ - performance of asphalt concrete plant; $W_{\mathrm{T}}$ - performance of the transport unit; $P_{\mathrm{y}}$ - performance of a laying link; 0,271 - coefficient reflecting influence on production of work's intensity of unaccounted factors; 0,385 / 0,051/ 0,565 coefficients of influence of technological factors on the intensity of the implementation of road renovations.

The correlation coefficient $-0,98$, standard deviation 0,107 . Due to the high performance of the asphalt

\footnotetext{
* Corresponding author: $\underline{\text { mkarpushko@gmail.com }}$
} 
concrete plants their impact is 1,4 times less (coefficient of influence 0,385). Influence of motor transport insignificant $(0,051)$.

Nowadays in development of construction and repair of asphalt concrete pavements technology there is tendency to use high-productive asphalt pavers. Pavers of American production are characterized by high productivity, which is provided by a high operating speed and large paving width [1, 2]. Asphalt pavers of European production: «Demag», «Vogele», «ABG», «Baukema», «Dynapac», etc., in addition to increased productivity, have the ability to pre-compact the mixture to standard coefficient of consolidation with active working elements - tamper and vibratory plates (Figure 2).

These companies produce both tracked and wheeled pavers with different paving width: 0,80-16,0 m (tracked), 1,5-9,1 m (wheel); and capacity up to 1500 tons / hour (Vogele Super 2500), up to 1900 tons / hour (crawler asphalt paver Vogele Super 1900-2). Hydraulic spreader or hinged widener can increase the width of the working elements of the paver, with maximum thickness of the layer of $110-500 \mathrm{~mm}$ at an operating speed of 1,08 $-110 \mathrm{~m} / \mathrm{min}$. [3].

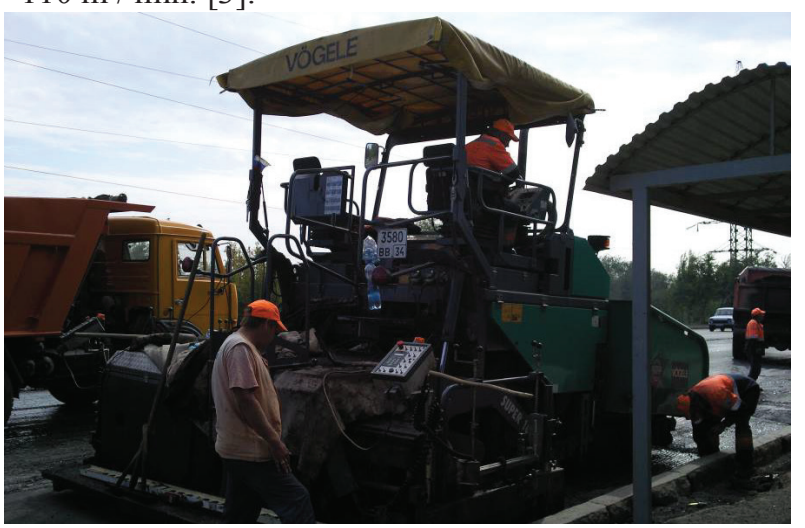

Fig. 2. Mix laying by Vogele Super 1803-1 asphalt paver on Universitetsky Ave. in Volgograd, Russia.

Tracked and wheeled pavers, which are capable to provide a preliminary compaction of asphalt-concrete mixes, are produced by Russian companies [1]. Track models: DS-195, DS-179, DS-189; wheeled: DS-155, DS-173, SD-404b, DS-191, AK-7, DS-181 (Figure 3).

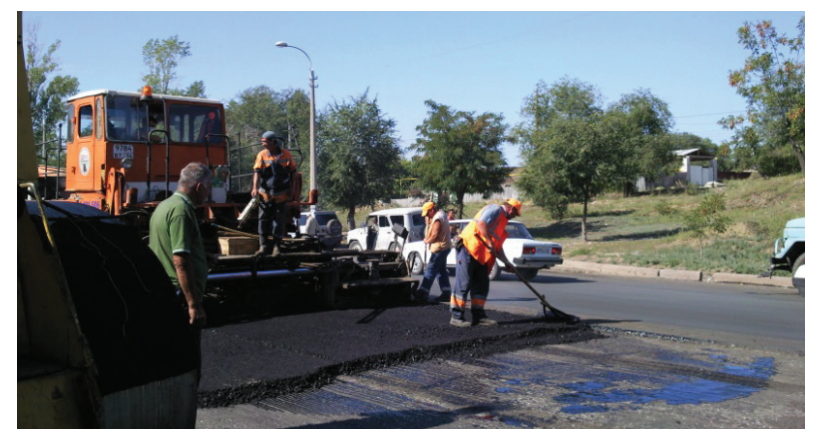

Fig. 3. Repair of the pavement on the Elektrolesovskaya street, Volgograd, Russia (asphalt paver DS-191-506).
If laying is made by strips of different width and at the same time one or several asphalt pavers are used, different methods of work's organization are applied accordingly. For example, if laying is made on width of $1,0-12,0 \mathrm{~m}$ - laying is made by one asphalt paver. With a laying width of $9 \mathrm{~m}$ and more two and more asphalt pavers are used. If the technology requires the work of several asphalt pavers, then subject distance between them is $10-15 \mathrm{~m}$ (maximum $30 \mathrm{~m}$ ) and they are put with a ledge.

Knowing the cooling time of asphalt mixture at the permissible temperature intervals ( $\tau y)$ and operating speed of the paver $(\mathrm{Va} / \mathrm{y})$, you can determine the length of the strip to be laid for roller operations (Sy):

$$
S_{y}=V_{\mathrm{a} / \mathrm{y}} \cdot \tau_{y}
$$

In order to make the process of paving continuous and in the right temperature range, it is recommended to take the length of laying strips equal to the length of the clamping, and the length of the strip to be compacted by the rollers should be more than $10-15 \mathrm{~m}$, in order to ensure their acceleration and braking, as well as to satisfy the following condition $[4,5]$ :

$$
S_{y}=[S]
$$

where $[S]$ - recommended minimum length of the seal area, m; $S y$ - length of the strip, to be laid by paver for the same time, $\mathrm{m}$.

The efficiency of paver unit is determined by the productivity of asphalt paver, as it distributes the mixture on divisions, provides all required parameters of layer and ultimately provides front work operation for roller link. Modern models of asphalt pavers of European and American manufacturers have a maximum passport capacity 500-700 tons / hour. It is calculated from the conditions of the maximum possible thickness and width of the packing, operating speed and uniform movement of the stacker.

In production conditions, the coincidence of all the parameters is rare, so in practice the productivity of machines is 1,5-2 times or 250-350 tons / hour lower, in some cases does not exceed 100-150 tons per hour, in rare cases it reaches 150-200 tons / hour, which is associated with a low supply of a mixture from asphalt concrete plant. Therefore, this performance is taken into account while units recruiting. But there is a reserve of up to 1,5-2 times in increasing the intensity of work, which confirms a comparison of the possible and actual productivity of pavers.

Productivity of paver is distributed according to the normal law or $\beta$-distribution (Figure 4 ). The coefficient of variation varies in the range $0,17-0,56$.

Calculations of the productivity of pavers according to formulas overestimate the shift production of machines to $20-30 \%$ [7]. Assigning performance based on time norms, is only possible for individual domestic pavers. 


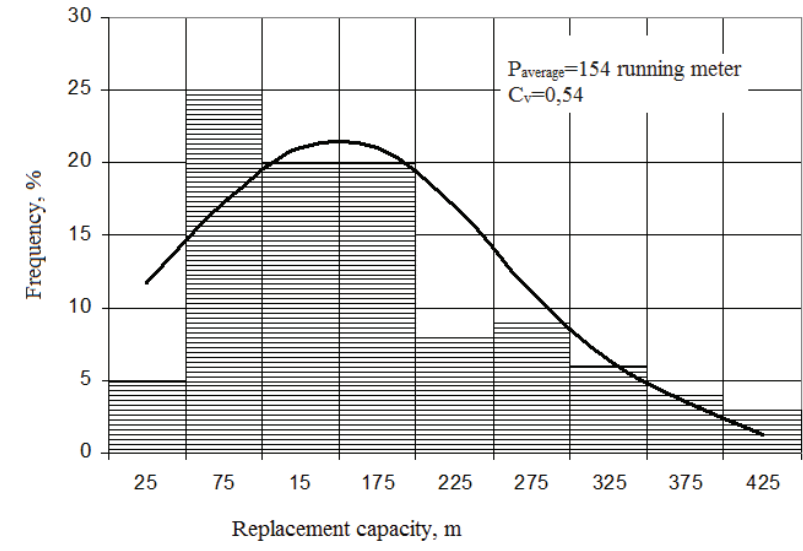

Fig. 4. Distribution of replacement capacity of DS-1 paver (according to [6]).

On the basis of the regression dependences of the maximum permissible thickness of the mixture laying in the coating $h$, machine shifting from width $\mathrm{H}$ and working speed of the paver perform the justification of the performance of new modern pavers. Statistics were compiled for 98 asphalt pavers [3], which allowed to propose the following dependencies:

For crawler pavers:

$$
P_{y}=\frac{0,0019 \cdot H^{0,359} \cdot h^{2,102} \cdot V_{\rtimes}^{0,112}}{K_{\odot} \cdot K_{\sqsubset}}, \mathrm{t} / \mathrm{h}
$$

For wheeled pavers:

$$
P_{y}=\frac{0,0007 \cdot H^{1,039} \cdot h^{2,022} \cdot V_{\star}^{0,299}}{K_{\circ} \cdot K_{г}}, \mathrm{t} / \mathrm{h}
$$

where $K_{0}$ - coefficient that takes into account the decrease in pavers productivity in the dark, as the road reconstruction works in urban conditions is preferably carried out at night time (Table 1); $K_{п}$ - coefficient of influence on labor productivity in warm season of weather conditions (Table 2).

Table 1. Values of coefficient $K_{\mathrm{o}}$, depending on work place lighting conditions [8].

\begin{tabular}{|c|c|c|}
\hline \multicolumn{2}{|c|}{ Lighting conditions } & $\mathrm{K}_{\mathrm{o}}$ \\
\hline \multirow{3}{*}{$\begin{array}{c}\text { Natural } \\
\text { lighting }\end{array}$} & Normal, daytime & 1,0 \\
\cline { 2 - 3 } & $\begin{array}{c}\text { Bright sunny days in southern } \\
\text { regions }\end{array}$ & $1,1-1,2$ \\
\cline { 2 - 3 } & Twilight, moonlit night & $1,4-1,6$ \\
\hline Artificial & Normal, using fixtures & $1,1-1,2$ \\
\cline { 2 - 3 } lighting & With spotlights & $1,3-1,4$ \\
\hline
\end{tabular}

Table 2. Values of operating conditions coefficient $K_{\text {п }}$ for warm period of the year [8].

\begin{tabular}{|c|c|c|}
\hline \multicolumn{2}{|c|}{ Weather } & \multirow{2}{*}{$\mathrm{K}_{\text {п }}$} \\
\cline { 1 - 2 } Air temperature, ${ }^{\circ} \mathrm{C}$ & Precipitation & \\
\hline $0 \ldots+25$ & Dry weather & 1,0 \\
\hline$+10 \ldots+25$ & Precipitation $>5 \mathrm{~mm} /$ day & $1,2-1,3$ \\
\hline $0 \ldots+10$ & Precipitation $>5 \mathrm{~mm} /$ day & $1,4-1,5$ \\
\hline Above +25 & Dry weather & $1,4-1,6$ \\
\hline
\end{tabular}

When the weather is dry and the ambient temperature is from 0 to $+25^{\circ} \mathrm{C}$ maximum productivity is reached, which decreases during rain and wind conditions, as well as at the exit out of comfortable temperature range limits. The correlation coefficient $-0,80-0,85$, standard deviation 0,42 .

All of the above indicates the complexity of fulfilling the specified parameters of the asphalt-concrete paving. Today, without the use of high technologies, it is impossible to obtain high-quality road surface. The proposed approach to the calculation of the operational productivity of asphalt pavers takes into account technical characteristics and conditions of works production and contributes to the reliability of decisions on organization and management of road maintenance works on urban roads.

\section{References}

1. V.K. Kuznetsov, Maintenance and current repair of city roads. Moscow, Alfa-Print, P. 151 (1998)

2. M.P. Kostelyov, Modern methods and means of pavement patching, Road engineering, № 5, pp. 5659 (2001)

3. Catalogue of road construction equipment, St. Petersburg, (2000-2008)

4. A.V. Zubkov, Technique of technological processes development of hot asphalt mixtures pavement's construction, Herald TSTU, vol. 13, № 1, P. 52 (2007)

5. A.V. Zubkov, Influence of factors on duration of hot asphalt mixtures laying during highways construction, Russia Roads of XXI century, № 4, pp. 42-45 (2006)

6. V.M. Mogilevich, Winter organization and technology of road construction, Moscow, P. 276 (1971)

7. A.Z. Apartsev, Flow charts and rules of laying and compaction of hot asphalt mixes during highways coatings application, St.-Petersburg; P. 51 (1966)

8. M. Eddous, Methods of decision-making, Moscow: Audit: UNITY, P. 590 (1997)

9. M.O. Karpushko, E.N. Karpushko, I.L. Bartolomei, World experience of operational management in construction, Globalization and its Socio-Economic Consequences 16th International Scientific Conference Proceedings. ZU - University of Zilina, 5th -6th October 2016, Rajecke Teplice, Slovak Republic, pp. 823-830 (2016)

10. E. Popkova, S. Meshkova, E. Karpunina, E. Karpushko, M. Karpushko, Developing countries as new growth poles of post-crisis global economy, Contemporary Economics, vol. 10, № 2, pp. 175186 (2016)

11. E.N. Karpushko, I.L Bartolomei, M.O. Karpushko, Study of using the possibility of textile sand piles at the base of the automobile road folded by saline soils, Procedia Engineering. vol. 150, pp. 2287-2292 (2016) 